\section{JURNAL ABDIMAS

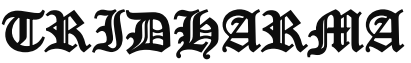 AtA}

P-ISSN 2715-7105, E-ISSN 2716-070X

Jurnal ABDIMAS Vol. 2, No. 1, Januari 2021,Hal (25-34)

@Prodi Manajemen Fakultas Ekonomi Universitas Pamulang

Email: abdimasjurnal.unpam@gmail.com Telp: (021) 741-2566

\title{
FINANCIAL PLANNING FOR MILLENIALS IN PANDEMIC ERA
}

\author{
Vega Anismadiyah, Hadijah Febriana, Jeni Irnawati, \\ Vidya Amalia Rismanty, Wirawan Suryanto \\ Dosen Prodi Manajemen Fakultas Ekonomi Universitas Pamulang \\ Email : dosen02218@unpam.ac.id, dosen02182@unpam.ac.id, dosen02228@unpam.ac.id, \\ dosen02270@unpam.ac.id, dosen02244@unpam.ac.id
}

\begin{abstract}
ABSTRAK
Tujuan dari kegiatan Pengabdian Kepada Masyarakat ini adalah untuk melaksanakan salah satu Tri Dharma Perguruan Tinggi. Selain itu, melalui kegiatan Pengabdian Kepada Masyarakat ini, keberadaan perguruan tinggi diharapkan dapat memberikan kontribusi besar kepada pengembangan dan penerapan keilmuan dalam masyarakat.

Metode kegiatan yang digunakan adalah tim pelaksana mengunjungi SMK Muhammadiyah Parakan yang beralamat di Jalan Pendidikan Komp. Ritan Rt. 03 Rw. 09 Desa Parakan Kelurahan Pondok Benda Kecamatan Pamulang Kota Tangerang Selatan dan memberikan pelatihan mulai tanggal 19 - 21 November 2020. Pelatihan ini bertujuan agar siswa dan siswi SMK Muhammadiyah Parakan yang masih berusia remaja memahami pentingnya financial planning atau perencanaan keuangan untuk meraih tujuan-tujuan keuangan yang lebih besar dan bisa menerapkan perencanaan keuangan tersebut dalam kehidupannya mulai sekarang, terutama sebagai bekal dalam menghadapi kesulitan ekonomi seperti di masa pandemi saat ini.

Hasil kegiatan Pengabdian Kepada Masyarakat ini adalah bertambahnya keilmuan dan keterampilan siswa-siswi SMK Muhammadiyah Parakan, khususnya di bidang keuangan yaitu perencanaan keuangan yang akan menjadi bekal mereka dalam mengelola keuangan, baik di masa normal maupun di masa kesulitan ekonomi seperti sekarang .

Ilmu yang didapatkan pada kegiatan Pengabdian Kepada Masyarakat ini diharapkan mampu memberikan semangat dalam menyampaikan pengetahuan dan memberikan motivasi serta berkontribusi bagi generasi muda, baik di lingkungan sekolah, kampus maupun masyarakat.
\end{abstract}

Kata kunci : Financial Planning, Millenials, Pandemic Era

\section{ABSTRACT}

The purpose activity is to carry out one of the obligations of the Tri Dharma Perguruan Tinggi. In addition, through this activity, the existence of university is expected to make a major contribution to the development and application of science in public.

The activity method used was the implementation team visiting SMK Muhammadiyah Parakan which is located at Jalan Pendidikan Komp. Ritan Rt. 03 Rw. 09 Parakan Village, Pondok Benda Village, Pamulang District, South Tangerang City and provide training from November $19^{\text {th }}$ to November $21^{s t}$ 2020. This training aims to make students of Muhammadiyah Parakan Vocational School who are still teenagers, understand the importance of financial planning to achieve bigger financial goals and to apply financial planning in daily life, especially as a provision for facing economic difficulties during this current pandemic.

The result of this activity is the increase in knowledge and skills of Muhammadiyah Parakan Vocational School students, especially in the financial sector, namely financial planning which will become their provisions in managing finances, both in normal times and in difficulties times like now. 


\section{JURNAL ABDIMAS

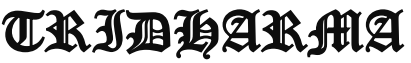 AtA}

P-ISSN 2715-7105, E-ISSN 2716-070X

Jurnal ABDIMAS Vol. 2, No. 1, Januari 2021,Hal (25-34)

@Prodi Manajemen Fakultas Ekonomi Universitas Pamulang

Email: abdimasjurnal.unpam@gmail.com Telp: (021) 741-2566

The knowledge gained in this activity is expected to be able to provide enthusiasm in conveying knowledge and provide motivation and contribute to the younger generation, both in the school, campus and community environment.

\section{Keywords: Financial Planning, Millennials, Pandemic Era}

\section{PENDAHULUAN}

Pandemi Corona Virus Disease-19 atau lebih dikenal dengan Covid-19 saat ini masih melanda berbagai negara di dunia, termasuk Indonesia. Pandemi tersebut sangat mempengaruhi kehidupan masyarakat dunia karena penyebarannya sangat cepat. Pemerintah Indonesia mengambil beberapa kebijakan untuk memutus mata ranta penyebarannya. Salah satu kebijakan yang diambil adalah membatasi kegiatan yang memungkinkan banyak orang berkumpul. Hal tersebut sangat mempengaruhi perekonomian masyarakat Indonesia. Para buruh banyak yang dirumahkan karena pabrik atau tempat mereka bekerja tidak lagi beroperasi atau ditutup untuk waktu yang belum bisa ditentukan. Karyawanpun berkurang penghasilannya karena jam kerja dipangkas untuk mengurangi penyebaran virus ini. Masyarakat yang tidak memiliki tabungan kebingungan untuk menyambung hidup karena pandemi ini sudah berlangsung berbulan-bulan. Beruntunglah orang yang mengikuti saran Allah SWT seperti tertulis dalam Al Qur' an surat Al Israa ayat 27 yang artinya : "Sesungguhnya para pemboros itu adalah saudara-saudaranya syetan." Pandemi menjadi pembelajaran bagi kita agar kita mampu melakukan perencanaan dan pengelolaan keuangan agar kita tidak hidup boros dan mempunyai simpanan untuk masa depan.

Sebuah penelitian yang dilakukan oleh GoBear Indonesia merilis hasil riset bertajuk GoBear Financial Health Index (FHI) yakni survei keuangan yang melibatkan responden dari sejumlah negara di Asia Tenggara. Hasilnya menunjukkan bahwa kesadaran masyarakat Indonesia terkait perencanaan keuangan masih rendah. Hasil studi FHI mengungkapkan fakta menarik, seperti bahwa di usia 35 tahun, orang Indonesia bahkan belum memulai perencanaan keuangan dan di usia 41 tahun baru memulai perencanaan pensiun. Orang Indonesia juga merasa aman secara keuangan (nilai 7,5 dari skala 1-10), tetapi hanya $37 \%$ dari mereka yang memiliki tabungan untuk mencukupi kebutuhan hidup lebih dari 6 bulan bila mereka kehilangan sumber pendapatan utamanya.

Sebuah penelitian lain yang dilakukan oleh Survei Nasional Literasi dan Inklusi Keuangan Otoritas Jasa Keuangan (OJK) menyebutkan bahwa tingkat literasi keuangan masyarakat Indonesia baru mencapai angka 29,7 persen. Sementara itu, tingkat inklusi keuangan masyarakat Indonesia ada di angka 67,8 persen.

"Artinya dari 100 orang, yang punya produk keuangan ada sekitar 70 orang, sedangkan yang mengerti mengenai keuangan hanya sekitar 30 orang di antaranya," ujar Kepala Departemen Literasi dan Inklusi Keuangan OJK Sondang Martha di Jakarta, Kamis (29/8/2019).

Dengan tingkat literasi yang rendah, kata Sondang, seseorang bisa menerima empat akibat. Pertama, tidak memiliki perencanaan keuangan yang baik. Kedua, tidak memiliki tujuan keuangan. Ketiga, penempatan instrumen investasi yang tidak tepat. Keempat, terjebak oleh praktik investasi 'bodong', seperti yang sudah dia paparkan sebelumnya.

Salah satu persoalan yang dihadapi oleh SMK Muhammadiyah Parakan adalah kurangnya kesadaran siswa dan siswi serta masyarakat sekitar yang merupakan mitra sekolah dalam mengatur keuangannya. Hal ini berimbas pada kelancaran pembayaran SPP siswa ke sekolah, hanya sebagian saja yang lancar membayar biaya SPP setiap bulan, sementara sebagian lain memiliki tunggakan SPP berbulan-bulan. Hal ini terjadi cukup lama sebelum masa pandemi, di masa pandemi ini lebih banyak lagi yang menunggak pembayaran SPP.

Ketidakmampuan merencanakan keuangan (financial planning) membuat para remaja tersebut menjadi boros dan berperilaku 


\section{JURNAL ABDIMAS

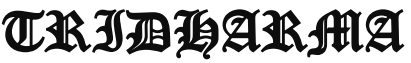 AtA}

P-ISSN 2715-7105, E-ISSN 2716-070X

Jurnal ABDIMAS Vol. 2, No. 1, Januari 2021,Hal (25-34)

@Prodi Manajemen Fakultas Ekonomi Universitas Pamulang

Email: abdimasjurnal.unpam@gmail.com Telp: (021) 741-2566 konsumtif demi mengikuti gaya hidupnya dan membuat mereka menjadi remaja yang tidak bertanggungjawab. Pemborosan dan perilaku konsumtif tersebut bisa diminimalkan dengan mengajarkan perencanaan keuangan kepada mereka. Melakukan perencaaan keuangan bukan hanya bisa dilakukan oleh orang dewasa yang sudah berkeluarga, tetapi harus diterapkan untuk dilakukan oleh para remaja. Remaja berasal dari bahasa Latin adolescare yang artinya tumbuh atau tumbuh untuk mencapai kematangan. Masa remaja adalah masa transisi dalam rentang kehidupan manusia, menghubungkan masa kanak-kanak dan dewasa (Santrock, 2003). Pada 1974, WHO (World Health Organization) memberikan definisi tentang remaja yang lebih bersifat kontekstual. Dari sisi biologis, remaja adalah individu yang berkembang dari saat pertama kali menunjukkan tanda-tanda seksual sekundernya sampai mencapai kematangan seksual. Dari sisi psikologis, remaja adalah individu yang mengalami perkembangan psikologis dan pola identifikasi dari kanakkanak menjadi dewasa. Dari sisi sosial ekonomi, remaja adalah individu yang mengalami peralihan dari ketergantungan sosial-ekonomi yang penuh kepada keadaan yang relatif mandiri.

Menurut Papalia \& Olds (dalam Jahja, 2012), masa remaja adalah masa transisi perkembangan antara masa kanak-kanak dan dewasa yang pada umumnya dimulai pada usia 12 atau 13 tahun dan berakhir pada usia akhir belasan tahun atau awal dua puluhan tahun. Batasan usia remaja menurut WHO adalah 12 sampai 24 tahun. Sementara menurut Menteri Kesehatan RI tahun 2010, batas usia remaja antara 10 sampai 19 tahun dan belum menikah (Widyastuti dkk, 2009).

Masa remaja merupakan masa pencarian identitas dirinya. Pada masa ini, peran orang tua dan lingkungan sangat penting agar remaja mengenal dirinya, beradaptasi dengan lingkungannya dan mampu menghadapi tantangan kehidupan.

Kurangnya peran orang tua dan lingkungan dalam masa pertumbuhan remaja, membuat mereka menjalani gaya hidup yang tidak terarah bahkan menyimpang. Gaya hidup seorang remaja saat ini sangat berkaitan erat dengan semakin berkembangnya teknologi informasi dan komunikasi. Dengan fasilitas teknologi dan informasi yang mereka miliki, mereka bebas mencari dan menentukan gaya hidup yang mereka mau.

Gaya hidup remaja saat ini cenderung konsumtif dan boros. Mereka membeli barang yang diinginkan, bukan barang yang dibutuhkan, karena begitu derasnya pengaruh lingkungan dan iklan produk. Uang saku yang diberikan orang tua selalu habis bahkan kurang untuk memenuhi gaya hidupnya.

Belum banyak remaja yang memiliki kesadaran tentang pentingnya perencanaan keuangan (financial planning). Padahal perencanaan keuangan (financial planning) sangat penting diterapkan sejak dini sebagai bekal kemampuan mengelola keuangan mereka di masa depan. Perencanaan keuangan (financial planning) merupakan sebuah proses yang dilakukan oleh seorang individu untuk memenuhi tujuan finansialnya melalui rencana keuangan yang menyeluruh. Individu yang sadar akan pentingnya perencanaan keuangan (financial planning) akan mampu mengelola keuangan yang dimilikinya dan mencegahnya mengeluarkan uang lebih banyak dari yang seharusnya serta memaksimalkan sumber pendapatan yang dimiliki sehingga dia mampu mencapai tujuan finansialnya.

Perencanaan keuangan (financial planning) menurut OJK merupakan seni pengelolaan keuangan yang dilakukan oleh individu atau keluarga untuk mencapai tujuan yang efektif, efisien dan bermanfaat, sehingga individu atau keluarga tersebut menjadi individu atau keluarga yang sesjahtera. Menurut Senduk (2001) perencanaan keuangan (financial planning) adalah proses merencanakan tujuan-tujuan keuangan jangka pendek maupun jangka panjang. Yang dimaksud tujuan keuangan adalah keinginan keuangan yang ingin direalisasikan. Gozali (2002) mendefinisikan rencana keuangan (financial planning) sebagai sebuah strategi yang apabila dijalankan bisa membantu Anda mencapai tujuan keuangan di masa datang. Dorimulu (2003) menyatakan bahwa perencanaan keuangan (financial planning) merupakan proses mencapai tujuan hidup yakni masa depan yang sejahtera dan bahagia lewat penataan keuangan. 


\section{JURNAL ABDIMAS

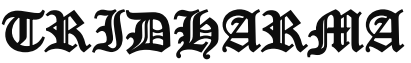 AtA}

SMK Muhammadiyah Parakan merupakan salah satu SMK di Tangerang Selatan yang diprakarsai oleh PDM kabupaten Tangerang Majelis Dikdasmen pada tahun 2007. Sekolah yang berlokasi di Jalan Pendidikan Komp. Ritan Rt. 03 Rw. 09 Desa Parakan Kelurahan Pondok Benda Kecamatan Pamulang ini didirikan sebagai salah satu upaya memenuhi keinginan masyarakat di wilayah tersebut untuk menyekolahkan putra dan putrinya di sekolah kejuruan yang berazaskan Islam. Bangunan dan tanah sekolah merupakan milik sendiri (Yayasan Muhammadiyah) dengan luas bangunan $1000 \mathrm{~m}^{2}$ dan luas lahan $2550 \mathrm{~m}^{2}$, kebutuhan akan air bersih tercukupi sehingga kondisi sekolah bersih dan nyaman. Banyaknya jumlah siswa dan siswi dari jurusan Akuntansi, Pemasaran, Administrasi Perkantoran dan Multimedia membuat SMK Muhammadiyah Parakan menjadi sekolah yang sangat potensial untuk menjadi lebih maju lagi di masa yang akan datang. Lokasinya yang cukup dekat dengan tempat tinggal warga, membuat SMK Muhammadiyah Parakan mendapatkan dukungan penuh dari masyarakat dan menjadi harapan warga agar anak-anak mereka kelak menjadi manusia yang Islami, handal, berwawasan dan terampil sesuai dengan visi SMK Muhammadiyah Parakan. Lokasi SMK Muhammadiyah Parakan tergolong aman dari premanisme dan sejenisnya sehingga siswa dan siswinya dapat belajar dengan tenang dan nyaman.

Siswa-siswi SMK Muhammadiyah Parakan, seperti remaja pada umumnya, belum mengetahui tentang apa itu perencanaan keuangan (financial planning) dan pentingnya perencanaan keuangan (financial planning) di masa depan mereka. Mereka belum memahami pentingnya mempelajari dan mempraktikkan perencanaan keuangan (financial planning) sejak dini. Ketidaktahuan ini disebabkan karena kurangnya informasi yang mereka terima dari orang tua atau lingkungan mereka. Karena seperti hasil beberapa penelitian yang sudah dipaparkan sebelumnya, kesadaran masyarakat Indonesia untuk melakukan perencanaan keuangan (financial planning) masih rendah. Padahal dengan melakukan perencanaan keuangan (financial planning), seseorang akan lebih bijak menyikapi mana yang lebih prioritas dan mana yang tidak saat membelanjakan uangnya. Perencanaan keuangan (financial planning) membuat seseorang mampu menggambarkan kondisi keuangan pribadinya sehingga ia akan mengalokasikan keuangannya dengan jelas dan memotivasinya untuk lebih giat dalam mengumpulkan uang.

\section{RUMUSAN MASALAH}

Salah satu persoalan yang dihadapi oleh SMK Muhammadiyah Parakan adalah kurangnya kesadaran siswa dan siswi serta masyarakat sekitar yang merupakan mitra sekolah dalam mengatur keuangannya. Hal ini berimbas pada kelancaran pembayaran SPP siswa ke sekolah, hanya sebagian saja yang lancar membayar biaya SPP setiap bulan, sementara sebagian lain memiliki tunggakan SPP berbulan-bulan. Hal ini terjadi cukup lama sebelum masa pandemi, di masa pandemi ini lebih banyak lagi yang menunggak pembayaran SPP.

Ketidakmampuan merencanakan keuangan membuat para remaja tersebut menjadi boros dan berperilaku konsumtif demi mengikuti gaya hidupnya dan membuat mereka menjadi remaja yang tidak bertanggungjawab. Pemborosan dan perilaku konsumtif tersebut bisa diminimalkan dengan mengajarkan perencanaan keuangan kepada mereka.

Gaya hidup remaja saat ini cenderung konsumtif dan boros. Mereka membeli barang yang diinginkan, bukan barang yang dibutuhkan, karena begitu derasnya pengaruh lingkungan dan iklan produk. Uang saku yang diberikan orang tua selalu habis bahkan kurang untuk memenuhi gaya hidupnya.

Siswa-siswi SMK Muhammadiyah Parakan, seperti remaja pada umumnya, belum mengetahui tentang apa itu perencanaan keuangan (financial planning) dan pentingnya perencanaan keuangan (financial planning) di masa depan mereka. Mereka belum memahami pentingnya mempelajari dan mempraktikkan perencanaan keuangan sejak dini. Ketidaktahuan ini disebabkan karena kurangnya informasi yang mereka terima dari orang tua atau lingkungan mereka. Karena seperti hasil beberapa penelitian yang sudah dipaparkan sebelumnya, kesadaran masyarakat Indonesia untuk melakukan perencanaan keuangan (financial planning) masih rendah. Padahal dengan melakukan perencanaan 


\section{JURNAL ABDIMAS

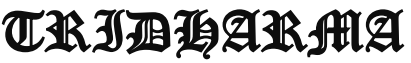 AtA}

P-ISSN 2715-7105, E-ISSN 2716-070X

Jurnal ABDIMAS Vol. 2, No. 1, Januari 2021,Hal (25-34)

@Prodi Manajemen Fakultas Ekonomi Universitas Pamulang

Email: abdimasjurnal.unpam@gmail.com Telp: (021) 741-2566 keuangan (financial planning), seseorang akan lebih bijak menyikapi mana yang lebih prioritas dan mana yang tidak saat membelanjakan uangnya. Perencanaan keuangan membuat seseorang mampu menggambarkan kondisi keuangan pribadinya sehingga ia akan mengalokasikan keuangannya dengan jelas dan memotivasinya untuk lebih giat dalam mengumpulkan uang.

Belum banyak remaja yang memiliki kesadaran tentang pentingnya perencanaan keuangan (financial planning). Padahal perencanaan keuangan (financial planning) sangat penting diterapkan sejak dini sebagai bekal kemampuan mengelola keuangan mereka di masa depan. Perencanaan keuangan (financial planning) merupakan sebuah proses yang dilakukan oleh seorang individu untuk memenuhi tujuan finansialnya melalui rencana keuangan yang menyeluruh. Individu yang sadar akan pentingnya perencanaan keuangan (financial planning) akan mampu mengelola keuangan yang dimilikinya dan mencegahnya mengeluarkan uang lebih banyak dari yang seharusnya serta memaksimalkan sumber pendapatan yang dimiliki sehingga dia mampu mencapai tujuan finansialnya.

\section{TUJUAN KEGIATAN}

Kegiatan pelatihan ini diharapkan mampu memberikan dampak jangka panjang bagi kehidupan siswa-siswi yang masih remaja.

a. Memberikan pengetahuan kepada siswasiswi SMK Muhammadiyah Parakan yang masih berusia remaja mengenai pentingnya perencanaan keuangan dalam mengatur dan mengelola keuangan pribadi atau keluarga untuk mencapai tujuan keuangan yang lebih besar.

b. Memberikan pengetahuan kepada siswasiswi SMK Muhammadiyah Parakan yang masih berusia remaja mengenai cara membuat perencanaan keuangan untuk pribadi maupun keluarga.

\section{TINJAUAN PUSTAKA \\ Perencanaan Keuangan}

Perencanaan

keuangan

menurut Financial Planning Standards Board Indonesia adalah proses untuk mencapai tujuan hidup seseorang melalui pengelolaan keuangan secara ter-integrasi dan terencana. Yang termasuk dalam tujuan hidup seseorang antara lain: menyiapkan dana pendidikan bagi anak, menyiapkan dana hari tua bagi dirinya dan pasangan hidupnya, menyiapkan dana untuk memiliki rumah, menyiapkan warisan bagi keluarga tercinta, menyiapkan dana untuk beribadah haji dan lain lainya.

Menurut Senduk (2001) perencanaan keuangan adalah proses merencanakan tujuan-tujuan keuangan jangka pendek maupun jangka panjang. Yang dimaksud tujuan keuangan adalah keinginan keuangan yang ingin direalisasikan.

Gozali (2002) mendefinisikan rencana keuangan sebagai sebuah strategi yang apabila dijalankan bisa membantu Anda mencapai tujuan keuangan di masa datang.

Dorimulu (2003) menyatakan bahwa perencanaan keuangan merupakan proses mencapai tujuan hidup yakni masa depan yang sejahtera dan bahagia lewat penataan keuangan.

Dari definisi itu, maka perencanaan keuangan itu secara konsep merupakan suatu aktifitas yang terdiri dari beberapa elemen sebagai berikut:

1) Harus ada tujuan-tujuan financial yang mau dicapai,

2) Harus ada jangka waktu atau periode untuk memenuhi tujuan tersebut,

3) Harus ada action plan yang jelas dan praktis untuk dilakukan,

4) Harus ada sumber daya yang bisa digunakan untuk menjalankan action plan.

5) Harus ada sejumlah faktor resiko yang terkait dengan pilihan sumber daya.

Jika ternyata ada satu elemen saja yang hilang, maka konsep perencanaan keuangan itu sudah tidak ada alias bubar. Fakta lapangan, masih banyak individu yang kerap mengaku punya rencana keuangan, tetapi tidak bisa menyebutkan tujuan finansialnya secara pasti. Atau ada juga yang punya tujuan-tujuan financial tetapi tidak memiliki action plan yang jelas untuk mencapai tujuannya tersebut.

Selain itu, perencanaan keuangan adalah sebuah proses yang tidak pernah berhenti dan selalu berkelanjutan. Hal ini dikarenakan keadaan keuangan seseorang atau sebuah keluarga akan selalu berubah-ubah sejalan dengan perubahan kebutuhan keuangan, keadaan ekonomi, dan tahapan kehidupan. 


\section{JURNAL ABDIMAS

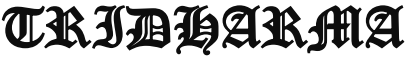 AtA}

P-ISSN 2715-7105, E-ISSN 2716-070X

Jurnal ABDIMAS Vol. 2, No. 1, Januari 2021,Hal (25-34)

@Prodi Manajemen Fakultas Ekonomi Universitas Pamulang

Email: abdimasjurnal.unpam@gmail.com Telp: (021) 741-2566
Perencanaan keuangan yang baik akan menghasilkan sebuah rencana keuangan (financial plan) yang jelas dan memudahkan si pemilik rencana untuk mencapai tujuan finansialnya. Rencana keuangan ini ibarat sebuah peta blueprint yang dapat menunjukkan kemana arah kondisi keuangan individu atau keluarga akan berjalan. Sebuah rencana keuangan yang komprehensif dan lengkap haruslah terdiri dari empat bagian berikut:

1) Manajemen kekayaan (wealth management),

2) Perencanaan asuransi (risk and insurance planning),

3) Perencanaan pensiun (pension planning),

4) Perencanaan pengalihan harta bawaan (pension planning).

Jadi, kalau ternyata rencana keuangan kita saat ini terkonsentrasi hanya di manajemen kekayaan saja, maka artinya konsep yg kita pahami mengenai sebuah rencana keuangan masih belum tepat.

\section{Pentingnya Perencanaan Keuangan}

Ada tiga hal dasar yang harus Anda pahami mengapa rencana keuangan itu penting :
1) Menggambarkan Kondisi Keuangan
2) Alokasi Dana Lebih Jelas
3) Memberi Motivasi

\section{Perencanaan keuangan sangat penting,} karena :
1) Menggambarkan kondisi keuangan
2) Alokasi dana lebih jelas
3) Memberi motivasi
4) Lebih hemat
5) Lebih bijak menggunakan uang

\section{Cara Membuat Perencanaan Keuangan}

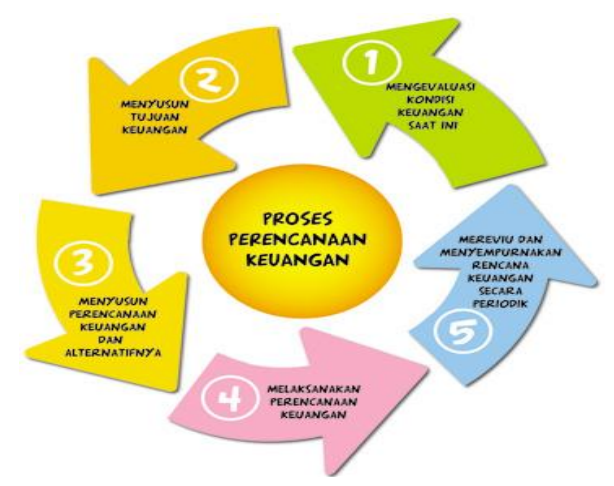

Gambar proses perencanaan keuangan
1) Mengevaluasi kondisi keuangan saat ini Melakukan analisis dengan memperhatikan kondisi terkini, seperti status perkawinan, jumlah anggota keluarga, kondisi pekerjaan, usia, kondisi kesehatan, dan lain-lainnya.

2) Menyusun tujuan-tujuan keuangan

Disusun tujuan-tujuan yang ingin dicapai, baik dalam jangka panjang maupun jangka pendek, seperti :

* Memiliki tabungan di bank sebanyak 20 juta pada 2 tahun ke depan,

* Ingin memiliki rumah sendiri pada 10 tahun ke depan,

* Memiliki mobil pribadi 3 tahun ke depan,

* Menunaikan ibadah haji 15 tahun ke depan.

3) Menyusun perencanaan keuangan dan alternatifnya untuk mencapai tujuantujuan keuangan

Perencanaan keuangan dapat berupa kegiatan yang akan dilakukan dan bauran produk keuangan yang akan digunakan, dikaitkan dengan jangka waktu pencapaiannya.

Misalkan :

* Membayar sebesar Rp. 350.000/bulan untuk premi asuransi pendidikan anak selama 10 tahun

* Menabung sebesar Rp. 500.000/bulan untuk dana naik haji selama 15 tahun

* Mencicil sebesar Rp. 1,5 juta/bulan untuk kredit pembelian mobil selama 10 tahun

4) Melaksanakan perencanaan keuangan yang sudah tersusun dengan disiplin

Setelah proses pengaturan dalam rencana keuangan dilakukan, tidak akan berhasil tanpa adanya komitmen melakukan apa yang sudah dibuat. Oleh karena itulah sebagai gambaran coblah untuk disiplin pada diri sendiri. Bahkan, langkah sederhana yang bisa dilakukan misalnya saja ketika tidak melakukan tindakan yang direncanakan kamu harus menghukum dirimu sendiri, hukuman ini tentu saja dilakukan dengan cara yang prefrentif jangan sampai menyakiti diri sendiri. Contoh hukuman prefensitif ini misalnya saja dengan tidak jajan seharian, 


\section{JURNAL ABDIMAS

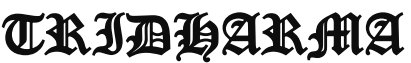 AtA}

dengan tidak makan siang, ataupun tindakan yang lainnya.

5) Mereviu dan menyempurnakan rencana keuangan secara periodik untuk menyesuaikan kondisi keuangan terkini

Kondisi keuangan seseorang bisa berubah. Misalnya seperti : lahirnya anggota keluarga baru, mengalami sakit yang membutuhkan biaya besar dan terganggunya sumber penghasilan keluarga, meningkatnya pendapatan secara signifikan, dan lain-lain. Jika terjadi perubahan, maka proses perencanaan keuangan akan dilakukan lagi dimulai dari awal proses (mengevaluasi kondisi keuangan terkini) dan diteruskan dengan proses-proses berikutnya.

\section{Manfaat Financial Planning}

* Panduan untuk mengelola keuangan

* Memaksimalkan sumber pendapatan yang dimiliki

* Melakukan penghematan

* Memulai investasi dan memiliki pendapatan pasif

* Mengurangi kecemasan akan masa mendatang

* Mewujudkan impian

\section{METODE PELAKSANAAN}

Metode kegiatan pengabdian kepada masyarakat ini dibagi menjadi beberapa tahap. Tahap pertama adalah identifikasi masalah yang dilakukan sebagai langkah awal untuk merumuskan apa saja yang akan dijadikan bahan untuk perancangan sistem dan materi pelatihan dalam kegiatan pengabdian kepada masyarakat ini.

Tahap berikutnya yaitu melakukan survei lapangan ke SMK Muhammadiyah Parakan sebagai tempat dilaksanakannya kegiatan. SMK Muhammadiyah Parakan beralamat di Jalan Pendidikan Komp. Ritan Rt. 03 Rw. 09 Desa Parakan Kelurahan Pondok Benda Kecamatan Pamulang Kota Tangerang Selatan. Tim pelaksana kemudian melakukan proses wawancara dan diskusi dengan pihak SMK Muhammadiyah Parakan untuk mengidentifikasi permasalahan yang ada dalam lingkungan siswa intra sekolah untuk kemudian merumuskan solusi dan penyelesaiannya serta menentukan keluaran yang diharapkan oleh mitra. Pada tahap ini anggota tim pelaksana berdiskusi menentukan tema dan materi yang akan disampaikan, bahan dan alat yang diperlukan, serta persiapan teknis lainnya yang dibutuhkan untuk kelancaran pelaksanaan kegiatan pengabdian kepada masyarakat ini. Permasalahan yang ditemukan pada siswasiswi remaja generasi milenial di SMK Muhammadiyah Parakan adalah belum mengetahui pentingnya perencanaan keuangan dalam kehidupan.

Tahap berikutnya adalah pelaksanaan kegiatan. Kegiatan ini dilaksanakan di tempat mitra, SMK Muhammadiyah Parakan, yang beralamat di Jalan Pendidikan Komp. Ritan Rt. 03 Rw. 09 Desa Parakan Kelurahan Pondok Benda Kecamatan Pamulang Kota Tangerang Selatan, pada hari Kamis 19 November 2020 sampai dengan hari Sabtu 21 November 2020 mulai pukul 10.00 sampai pukul 14.00 WIB. Kegiatan ini dilakukan dengan memberikan penyuluhan kepada siswa-siswi di SMK Muhammadiyah Parakan yang tergolong masih berusia remaja yang termasuk generasi milenial tentang pentingnya perencanaan keuangan, mengapa kita harus membuat perencanaan keuangan, manfaat membuat perencanaan keuangan dan cara membuat perencanaan keuangan. Penyampaian materi menggunakan metode presentasi dengan media Microsoft Power Point. Peserta yang mengikuti kegiatan ini sebanyak 15 orang. Peserta adalah siswasiswi pilihan dari berbagai jurusan mulai dari kelas X sampai dengan kelas XII.

Pihak mitra, yaitu SMK Muhammadiyah Parakan menyediakan ruang kegiatan yang memadai dan nyaman. Hal yang perlu diperhatikan yaitu cara mengatur (formasi) tempat duduk. Karena masih berada di masa pandemi, maka peserta dibatasi hanya 15 orang dan pengaturan tempat duduk serta pelaksanaan kegiatannya disesuaikan dengan protokol kesehatan (duduk diatur agar berjarak, tetap menggunakan masker, mencuci tangan setelah kegiatan, dan protokol kesehatan lainnya).

Untuk menunjang lancarnya pelaksanaan kegiatan ini, diperlukanbeberapa alat bantu/media pembelajaran tertentu, yaitu :
1) LCD (Liquid Crystal Display)
2) Laptop
3) Spidol 


\section{JURNAL ABDIMAS

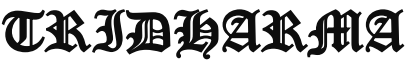

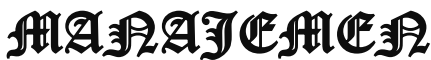

P-ISSN 2715-7105, E-ISSN 2716-070X

Jurnal ABDIMAS Vol. 2, No. 1, Januari 2021,Hal (25-34)

@Prodi Manajemen Fakultas Ekonomi Universitas Pamulang

Email: abdimasjurnal.unpam@gmail.com Telp: (021) 741-2566
4) White board

5) Buku catatan

Tahap terakhir dalam kegiatan pengabdiang kepada masyarakat ini yaitu tindak lanjut dari pelaksanaan kegiatan ini. Pada tahap ini dilakukan diskusi atau tanya jawab tentang permasalahan seputar perencanaan keuangan yang dihadapi siswasiswi sebagai generasi milenial, membahas materi perencanaan keuangan serta tips membuat rencana keuangan yang baik, kemudian dilakukan simulasi perencanaan keuangan pribadi masing-masing siswa-siswi.

Kegiatan pengabdian kepada masyarakat ini bertujuan untuk membuat siswa siswi SMK selaku generasi milenial menyadari pentingnya perencanaan keuangan dalam kehidupannya dan mulai membuat perencanaan keuangan pribadi. Pengetahuan ini diharapkan dapat ditularkan pula kepada anggota keluarga mereka. Target lain yang ingin dicapai dalam kegiatan pengabdian kepada masyarakat ini adalah timbulnya motivasi dalam diri tim pelaksana kegiatan untuk membuat sebuah tulisan ilmiah terkait Financial Planning For Millenials in Pandemic Era dan mempublikasikan hasil tulisan tersebut ke dalam jurnal Pengabdian Kepada Masyarakat.

\section{HASIL DAN PEMBAHASAN Hasil Kegiatan}

Berdasarkan wawancara, tanya jawab dan pengamatan langsung selama kegiatan berlangsung, kegiatan pengabdian pada masyarakat ini memberikan hasil sebagai berikut :

a. Meningkatnya pengetahuan siswasiswi SMK Muhammadiyah Parakan mengenai perencanaan keuangan yang harus dimiliki sejak muda agar bisa membuat rencana keuangan terbaik untuk masa depannya.

b. Meningkatnya motivasi siswa-siswi SMK Muhammadiyah Parakan untuk membuat perencanaan keuangan dan menerapkannya dalam keseharian mereka.

Faktor Pendukung dan Faktor Penghambat Beberapa faktor yang mendukung terlaksananya kegiatan pengabdian pada masyarakat ini adalah besarnya minat dan antusiasme peserta selama kegiatan, sehingga kegiatan berlangsung dengan lancar dan efektif. Sedangkan faktor penghambatnya adalah keterbatasan waktu pelatihan dan fasilitas peralatan yang masih minim.

\section{Pembahasan}

Kegiatan Pengabdian ini dilakukan di SMK Muhammadiyah Parakan. Tema yang diambil adalah Financial Planning For Millenials in Pandemic Era. Selama pelaksanaan kegiatan, siswa-siswi antusias mengikuti karena ini hal yang masih baru bagi mereka. Ketertarikan mereka dikuatkan dengan adanya partisipasi aktif baik, baik memberikan jawaban dan tanggapan dari moderator dan pemateri, maupun memberi pertanyaan kepada moderator dan pemateri. Kegiatan berlangsung dengan tertib dan lancar karena SMK Muhammadiyah Parakan sangat mendukung kegiatan ini dengan membantu menyiapkan tempat dan mengkondisikan siswa-siswinya agar siap mengikuti kegiatan ini.
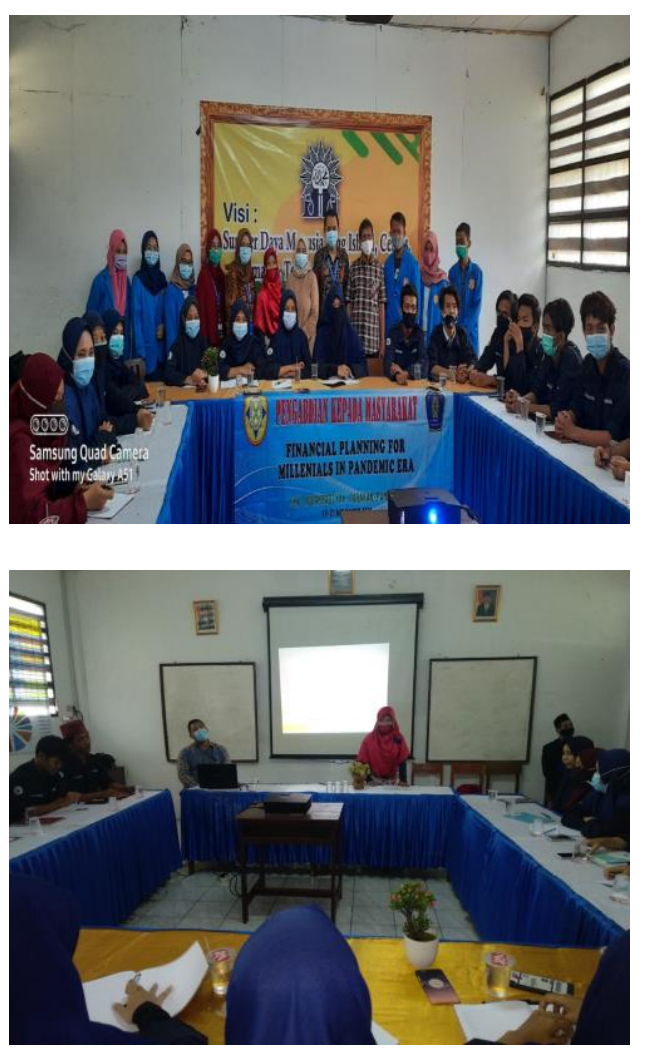


\section{JURNAL ABDIMAS

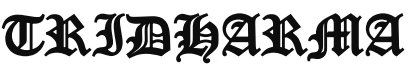

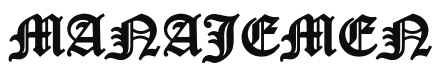

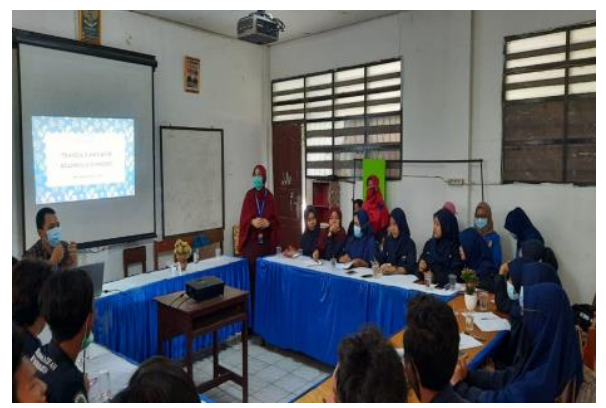

\section{KESIMPULAN DAN SARAN Kesimpulan}

Dari kegiatan pengabdian pada masyarakat ini dapat disimpulkan bahwa:

1. Pengetahuan dan pemahaman siswa dan siswi SMK Muhammadiyah Parakan tentang pentingnya perencanaan keuangan di masa pandemi ini menjadi bertambah.

2. Semakin meningkatnya minat siswa dan siswi untuk membuat perencanaan keuangan pribadi dan menerapkannya dalam keseharian mereka.

\section{Saran}

Mengingat besarnya manfaat kegiatan pengabdian pada masyarakat ini, maka selanjutnya perlu:

1. Mengadakan sosialisasi dan pelatihan serupa pada siswa sekolah lain di Kecamatan yang lain, dengan materi yang serupa.

2. Adanya kesinambungan program pasca kegiatan pengabdian ini sehingga para siswa benar-benar dapat mengembangkan kemampuannya dalam membuat perencanaan keuangan.

\section{DAFTAR PUSTAKA}

Ida Kurnia Putri. (2016). Perencanaan Keuangan Pada Mahasiswa Ekonomi Islam Di Yogyakarta. JIE Lariba Vol. 2 (1) 2016 .

Ismail, Gopar. Perencanaan Keuangan Keluarga. OJK
Pasaribu, V. L. D., Susanti, F., \& Hartuti, E. T. K. (2019). Memotivasi Siswa dan Siswi SMK Letris Indonesia di Dalam Menentukan Pilihan Untuk Melanjutkan Pendidikan Atau Bekerja Setelah Lulus Sekolah. Jurnal Pengabdian Dharma Laksana, 1(2), 161-172.

Pasaribu, V. L. D., Agrasadya, A., Shabrina, N., \& Krisnaldy, K. (2020). MENJADI ENTERPRENEUR MUDA YANG MEMILIKI JIWA LEADERSHIP UNTUK MENGHADAPI MASA DEPAN. Abdi Laksana, 1(1).

Pasaribu, V. L. D., Elburdah, R. P., Sudarso, E., \& Fauziah, G. (2020). PENGGUNAAN MANAJEMEN WAKTU TERHADAP PENINGKATAN PRESTASI BELAJAR DI SMP ARAISIYAH. Jurnal ABDIMAS Tri Dharma Manajemen, 1(1).

Pasaribu, V. L. D., Sulaiman, S., Sutiman, S., Thaharudin, T., \& Purnomo, B. Y. (2020). PENGENALAN LETAK POSYANDU TERDEKAT DIKELURAHAN PISANGAN DENGAN MANAJEMEN PEMASARAN REVOLUSI 4.0 UNTUK MENINGKATKAN PENGETAHUAN MASYARAKAT LETAK DAN FUNGSI POSYANDU TERDEKAT PADA KELURAHAN PISANGAN. DEDIKASI PKM, l(1), 105-110.

Pasaribu, V. L. D., Oktrima, B., Prabowo, B., Arianto, N., \& Haryoko, U. B. (2020). PROGAM PENDAMPINGAN DAN PENYELENGGARAAN PENDIDIKAN ANAK PADA USIA DINI TERHADAP PRESTASI BELAJAR DILINGKUNGAN RT 020 RW 009. KEL GIRI PENI. KEC WATES. YOGYAKARTA. JURNAL LOKABMAS KREATIF, 1(1), 71-75.

Ridwan, M. (2015). The Handbook of Family Financial Planning. Febi UIN-SU Press. Medan.

Subiaktono. (2013). Pengaruh Personality Traits Terhadap Perencanaan Keuangan Keluarga. Jurnal Dinamika Manajemen, 4 (2) 2013, 149-160. 


\section{JURNAL ABDIMAS

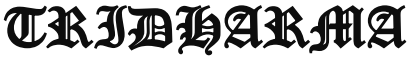 AtÃ}

P-ISSN 2715-7105, E-ISSN 2716-070X

Jurnal ABDIMAS Vol. 2, No. 1, Januari 2021,Hal (25-34)

@Prodi Manajemen Fakultas Ekonomi Universitas Pamulang

Email: abdimasjurnal.unpam@gmail.com Telp: (021) 741-2566 https://jdm.unnes.ac.id

http://dyaeducationblog.blogspot.com/2013/06

/definisi-perencanaan-keuangan.html https://pritaghozie.com/2012/08/06/pentingnya -perencanaan-keuangan/ https://sikapiuangmu.ojk.go.id/FrontEnd/CMS /Category/131 